

Deadlines: Orders for regular classified advertisements must reach the ACRL office on or before the second of the month preced Ing publication of the issue (e.g. September 2 for the October issue) Late job listıngs will be accepted on a space-avallable basıs after the second of the month

Rates: Classified advertisements are $\$ 5.00$ per line for ACRL members. $\$ 6.25$ for others. Late job notıces are $\$ 12.00$ per line for members. $\$ 14.00$ for others. Organizations submitting ads will be charged according to their membershıp status

Telephone: All telephone orders should be confirmed by a written order malled to $A C R L$ headquarters as soon as possible. Orders should be accompanied by a typewritten copy of the ad to be used in proofreading. An additional $\$ 10$ will be charged for ads taken over the phone (except late job notices or display ads).

Guidelines: For ads which list an applicatıon deadıne. that date must be no sooner than the 20th day of the month in which the notice appears (e g., October 20 for the October issue). All job announce ments should include a salary figure. Job announcements will be edited to exclude discrimınatory references. Applicants should be aware that the terms faculty rank and status vary in meaning among

JOBLINE: Call (312) 944-6795 for late-breakıng job ads for academic and research library positions. A pre-recorded summary of positioris Iisted with the service Is revised weekly; each Friday a new tape includes all ads recerved by 1:00 p.m the previous day. Each listing submitted will be carried on the recording for two weeks. The charge for each two-week listıng is $\$ 30$ for ACRL members and $\$ 35$ for non-members

Fast Job Listing Service: A special newsletter for those actively seekıng positions. This service lists job postıngs recelved at ACRL headquarters four weeks before they appear in C\&RL News. as wel as ads which. because of narrow deadlines. will not appear in C\&RL News. The cost of a six-morith subscription is $\$ 10$ for ACRL members and $\$ 15$ for non-members

Contact: Classified Advertising Dep t. ACRL. American Library Association, 50 E. Huron St. Chicago. IL 60611: (312) 944-6780.

\section{FOR SALE}

CATALOGERS! Say goodbye to Gale with Livia Press LC Cumula tive Classification schedules. Looseleaf or fiche. Cheap, convenient, always up to date. Livia Press, 967 Neilson St. Albany, CA 94706.

\section{POSITIONS OPEN}

ARCHITECTURE AND PLANNING/ENGINEERING LIBRARIAN. Responsiblities: The architecture and planning/engineering librar ian serves a dual role as head of the Architecture and Planning Branch Library and as the Auraria Library liaison to engineering fac ulty on the Aurarla campus. The Architecture and Planning Library supports the School of Architecture and Planning of the University of Colorado at Denver and its degrees in architecture, interior design. landscape architecture, urban design, and planning. The librarian is responsible for supervision of a library assistant and 1.5 FTE student staff, collection development, slide collection, specialized reference, and library instruction. Involvement in the community outreach program and fundraising activities is expected. Responsiblities as eng neering liaison include bibliographic instruction, collection development, and reference service at the Auraria Library. In addition general library faculty responsibilities include committee assign ments, publication, and service. Qualifications: ALA-accredited master's degree and an academic degree or experience in one of the above fields is required. Supervisory experience and excellent communication skills are strongly preferred. Experience in reference, slide collections, automated systems, collection development. and teaching is desired. Background: The Auraria Library occupies a unique position as the central point of information services in support of the programs of 3 diverse academic institutions on the Auraria campus in downtown Denver: the University of Colorado, Metropolitan State College, and the Community College of Denver. The library serves a population of 20.000 FTE students, 1.050 FTE faculty, and supports programs rangıng from vocational to graduate and professional training. The 27 professional staff and 100 support staff of the Auraria Library stress an active, service-oriented approach to library service through innovative programs and administration. Salary $\$ 19,000-\$ 29,000$ for a 12 -month contract. Faculty status, tuition benefits, 22 vacation days, and TIAA/CREF. All application materials must be received by January 5,1987 , for initial consideration. Recruitment will remain open until position is filled. Send letter of applicatıon, vita, and names and telephone numbers of 3 references to: Jay Schafer. Search Committee Chair. Auraria Library. Lawrence at 11 th St., Denver, CO 80204. AA. EEO employer

ART AND ARCHITECTURE SUBJECT SPECIALIST. Selects materials for relevant collections with particular emphasis on supporting the curriculum and research needs of the Department of Art and Art History and the School of Architecture and Environmental Design. Responsible for preparation, justificatıon. and disbursement of applıcable acquisitions allocations; for collection evaluation and policy formulatıon and updating: for RLG conspectus. evaluatıon. and verıfication work: and for preservatıon decisıons in areas of responsibility Develops and supervises an architectural slide collection. An equal amount of time is to be devoted to providing general and specialized reference services, biblıographic instruction, and in complling specialized bibliographies and study aids. Qualıficatıons: Accredited MLS, undergraduate or graduate work in both art and the social sciences, and at least two years experience as a professional librarian dealıng with collections/services in an academic or research library in art and/or architecture are required. A second master's degree in Art History. Architecture or related disciplınes and competency in Western European languages and collection development experience are highly preferred. Salary: \$25.000 or higher commensurate with qualificatıons: faculty status at the rank of Senior Assistant/Associate Librarıan. Closıng date for applications will be no earlier than December 31. 1986. Send letter of application and resume including the names of at least three references to. M E. State, Assistant to the Director for Personnel. University Librarıes. SUNY/ Buffalo, 432 Capen Hall. Buffalo. NY 14260 An EO/AA and Title IX Employer Ethnic Mınorities and Women are Encouraged to Apply

ASSISTANT DOCUMENTS LIBRARIAN to provide federal documents reference/instructional service. online searching. Assist in technical servicing of regıonal depository. Responsible for circulation. bınding, reference collection maıntenance. gifts and nondepository documents processing. Some general reference service: reference collectıon development in assigned subıects. Work some nights. weekends. Qualıfıcatıons: Master s degree from ALA. accredited program. course work in U S. documents and In general reference sources, familiarity with federal documents organization and classification system required. Social science background. documents experience and familiarıty with online searchıng desırable Initiative. organızational skills and strong interpersonal skills essentıal. Salary: $\$ 16.500$ minımum. Permanent. 12-month. fulltıme positıon, tenure track. Instructor rank. faculty equivalency Twenty-two days vacation. sick leave. Biue Cross/Blue Shield. State and TIAA/ CREF retırement plans. Openıng date for applicatıons. November 5. 1986 with projected startıng date March 15, 1987 Send letter of application. resume, names and addresses of three references, and trariscript to: Charies B. Osburn. Dean of Libraries. The University of Alabama. P O Box S. Tuscaloosa. AL 354879784 by January 9. 1987. The Unıversity of Alabama is an Equal Opportunity. Affirmatıve Action Employer.

ASSISTANT SERIALS LIBRARIAN (Search extended) The Dart. mouth College Library is seekıng qualıfied applicants for the position of Assistant Serials Librarıan. The Assistant Serials Librarıan reports to the Serials Librarian and is responsible for supervising the biblıographic control activities of the department in a technically sophisti. cated environment utılizıng the Dartmouth Onlıne Catalog. RLIN and OCLC. The Assistant Serials Librarian assists in the plannıng. development and implementation of serials control policies and procedures; coordinates biblıographic control actıvities for serıals throughout technical services areas; provides admınistratıve assistance to 
the department head: contributes to the plannıng and management of the department and Bıblıographic Control: participates in the selection. trainıng. supervision. and evaluation of staff: contributes to the implementation and continuing development of computer tech nology for the department. Qualifications: MLS from an ALA accredited library school; mınimum of three years experience in an academic or research library, some of which must have been in seri. ais cataloging or acquisitions: familarity with AACR2; experience with RLIN or another automated system: user-oriented philosophy effective communication and interpersonal skills. Previous experience with an automated serials control system is highly desirable Salary and rank commensurate with experience and qualıficatıons. Normal hirıng range: $\$ 18.500$ to $\$ 25.000$. TIAA/CREF. excellent fringes. Please send resume to: Phyllis E. Jaynes. Director of User Services. 115 Baker Library. Hanover. NH 03755. Applications will be reviewed beginning January 5. 1987. Dartmouth College is an AA. EEO. M/F employer

\section{ASSISTANT UNIVERSITY LIBRARIAN FOR ADMINISTRA-}

TION. Californıa State University. Sacramento, seeks an experienced librarian with evidence of practical managerial abilities and strong leadership qualities to join an administrative team comprised of the University Librarıan, the Associate University Librarian for Public Services, and the Assistant University Librarian for Systems Primary responsibilities are the management of fiscal operatıons for a library employing approxımately 36 full and part-time lıbrarians. 65 support staff and 220 student assistants with an annual budget of over $\$ 5$ million: the admınistration of academic personnel policıes and procedures: the direct supervision of the Library Support Services offıce (purchasing, receıving. mail. supplies. and buildıng maıntenance), and the Library Accountıng office; and the promotion of the professional development of lıbrarıans and support staff. Other responsibilities include participation in Library. University, and California State University system-wide committees and contribution to the mission of the University through scholarly development and publıc service. Qualıfıcations: Graduate degree from an ALA accredited library school or school of equivalent quality: minımum of six years progressively responsıble academic library experience including three years demonstrated leadership at the administratıve level (preferably including budget preparation and control) in the library at a large four-year institution of higher learning; demonstrated ability to deal with all levels of staff in a sensitive manner and to develop cooperative interaction with other campus units: knowledge of automated systems: abılity to work positively with faculty, university staff. and administrators: effective oral and written communication skills. Salary. $\$ 40.000-\$ 45.000$. dependıng on qualıfications. Write for a more detalled statement of position responsibilities. Application procedures: Send a letter (postmarked no later than January 26 1987) addressing the above qualifications, a current resume and names and addresses of 3 references. to: Joyce Ball. University Li brarıan. California State Unıversity, Sacramento. The Library, 2000 Jed Smith Drive. Sacramento. CA 95819-2695. An equal opportunity, affirmative action ınstitution

BIBLIOGRAPHER, The Romance Languages and Literatures. The Universıty of Chicago is seekıng a librarıan with advanced traınıng in Romance Languages and Literatures to manage collection development and provide subject reference services. The Biblıographer for Romance Languages and Literatures reports to the Associate Director for Publıc Services. Dutıes include selection of monographıc and serial material: evaluation, maintenance, and preservation of existing collections through addition, repair, replacement. or withdrawa of items: the cultivation of communicatıons with faculty and students to be responsive to needs, changes, and developments in the disci plines: and the provision of specialized reference service and ad vanced bibliographic instruction. Candidates with graduate degrees from an accredited library school in a Romance language and literature and prior experience in a research library will be given preference. Good reading knowledge of French. Italian. and Spanish required: workıng knowledge of German and Portuguese preferred Some familianity with other Western European languages desırable Salary range begins at $\$ 21.000$ per year. Appointment salary will be determıned based on experience and qualifications. Benefits in clude contributory retırement plan. health and life insurance. 22 days of vacation per year. 11 holıdays per year. 10 sick days per year, and tuition remission for both college age and younger children. Letters of application should include a curriculum vitae, and the names, addresses. and telephone numbers of 3 references. Receipt of applications before January 9. 1987. will assure consideration. Please submit nominations or applications to: Search Committee for Romance
Biblıographer, clo Personnel Officer, University of Chicago Library 1100 E. 57th St., Chicago, IL 60637. EOE

BIBLIOGRAPHIC INSTRUCTION COORDINATOR (Search extended). Under the direction of the Head of Reference, plans, coordinates, and evaluates the Library's bibliographic instruction program In additıon, works with eight reference librarians in providing genera reference service and freshman library orientation. Other responsbilities include reference consultation service, online searching, bıblographic instruction. and collection development in the subject ar eas of history language and political science Qualifications: ALA/MLS. two years successful public service experience required Demonstrated ability to plan. develop. coordinate. and evaluate biblographic instruction program; excellent oral and written commun cation skills; and ability to work effectively with the public and $\mathrm{co}$

\section{LIBRARY DIRECTOR Wittenberg University}

To develop the library as the intellectual center of the campus, Wittenberg University seeks a Director with: a commitment to building a program and collection appropriate to an undergraduate liberal arts college; a desire to work closely with faculty and students in their scholarly pursuits while providing creative direction and coordination for the library staff; an interest in applying new technologies within the traditional functions of a library.

Wittenberg University, located in Springfield, Ohio, and related to the Lutheran Church in America, is a selective, undergraduate liberal arts college with approximately 2,150 students. The library collection includes over 285,000 volumes and in excess of 1,000 periodicals. These are housed in a contemporary facility opened in the last five years. Staff of the library includes six professional-level positions. The Director reports to the Provost.

Qualifications: Professional degree in library science required; degree in a liberal arts discipline desirable; professional standing as evidenced by publications, involvement in professional organizations, or other activities required, plus breadth of experience, preferably some in a liberal arts college. Candidates should have a demonstrated leadership ability, experience in planning and budgeting, knowledge of developing trends in technology, skill in communicating with constituencies, breadth of intellectual and cultural interests, and a capacity for growth

Faculty rank; salary $\$ 33,000-\$ 40,000$, commensurate with qualifications.

Candidates should send a letter of application, current vita, and names and addresses of three references to:

\section{William M. Wiebenga, Provost Wittenberg University$$
\text { P.O. Box } 720
$$$$
\text { Springfield, } \mathrm{OH} 45501
$$

by January 9,1987

Wittenberg is an equal opportunity, affirmative action employer. 
workers highly desirable. Experience in online searching and microcomputer application and experience in media design and production desirable. Master's in relevant subject field preferable. Faculty status, tenure-track appointment, and good benefits. Salary range: $\$ 19,000-\$ 25,000$. The Robert Muldrow Cooper Library is an important research support facility with a collection of 13,500 serial titles and 1,260,000 volumes. The staff includes 23 librarians and 60 support staff. Candidates applying by January 19, 1987, will receive first consideration. Send letters of application with resume and names, addresses, and telephone numbers of three references to Myra Armistead, Chair, Bibliographic Instruction Coordinator Search Committee, Robert Muldrow Cooper Library, Clemson University. Clemson, SC 29634-3001. An EEO/AA employer

BIBLIOGRAPHIC INSTRUCTION LIBRARIAN, full-tıme $(9$ months) tenure track beginning August 15, 1987. MLS-ALA. 2nd Master's required for tenure. Experience in Reference-computer applications; science interest and academic library experience helpful. Salary in low $\$ 20,000$. Send application, resume. transcripts and three current references to: Michael Haeuser, Head Librarian, Gustavus Adolphus College, St. Peter, MN 56082. Deadline January 15. 1987

CATALOG LIBRARIAN at Brown University Library. Responsible for original cataloging of monographic materials in the general humanities, with an emphasis on the areas of art history, history and Romance literature Requirements: an MLS degree from an ALA accredited library school: knowledge of AACR2, MARC tagging, LC cataloging practices, reading knowledge of German and one Romance language; two years professional cataloging experience; ac ademic background or relevant experience in the humanities, preferably in art history and/or Romance literature. Hiring range. $\$ 21,000-\$ 24,200$, based upon experience. In order to insure consideration, please send letter of application, resume and names of three references by January 31, 1987, to: Norma Beach. Personne Office, Brown University. Providence. Ri 02912. An Equal Opportunity. Affirmative Action Employer

COLLECTION DEVELOPMENT/REFERENCE LIBRARIAN (Chinese), C. V. Starr East Asian Library. This position has primary re sponsibility for collection management and reference services for the Chinese research and instructional collection, which contains over 250.000 volumes. Collection management responsibilities in- clude selecting and deselecting material according to curricular and research needs of faculty and students: participation in making and evaluatıng collection development policies; implementing preservation and conservation policies; caring for rare books; and planning for future collection development programs in conjunction with system-wide policies, external networks and consortia. The incum bent will also share reference service responsibilities with other librarıans. Qualifications are an accredited MLS or master's degree in East Asian studies; fluency in oral and written Chinese and good communications skills in English: up-to-date knowledge of traditional Chinese subject areas and recent cultural and business changes in China; familiarıty with Chinese reference tools and new biblıographic techniques: knowledge of RLIN and other online systems: excellent organizational and interpersonal skills; and ability to work effectively with faculty and students. Salary ranges are: Librarian $\$ 22.000-\$ 28,600$; Librarian II: $\$ 24.000-\$ 32,400$. Excellent benefits include assistance with University housing and tuition exemption for self and family This position is available on or about May 1, 1987. Submit resume listing three references to: Box 35, Butler Library. CoIumbia University, 535 West 114th Street. New York. NY 10027 Deadline for applications is February 15, 1987. An Affirmative Action/Equal Opportunity Employer

COLLEGE ARCHIVIST/SPECIAL COLLECTIONS LIBRARIAN. Dickinson College, founded 1773, seeks a creative. energetic ar chivist/librarian to assume responsibility for its Archives and Special Collections Department housing historic and contemporary records from all divisions of the College plus rare books, photographs, and over 400 manuscript collections. This position involves continuing collection development and preservation, work with the Friends of the Library. provision of direct services to faculty and students through a busy instruction program, liaison with several academic departments, and active participation in the collegial management of the entire library. MA in History and ALA-accredited MLS highly de sirable. or advanced degree in history with significant archival expe rience. Salary: $\$ 23,000$ or higher depending on qualifications. Ful benefit package. Avallable July 1, 1987. Will conduct some interviews at ALA Midwinter. Send letter of application, vita and three let ters of recommendation (or university placement file) to: Annette Le Clair. Chairperson. Department of Library Resources. Dickınson College. Carlisle. PA 17013. Closing date February 1. 1987 An af firmative action, equal opportunity employer

\section{PRESERVATION OFFICER University of Maryland, College Park (Search Extended)}

The University of Maryland, College Park, invites nominations and applications for the position of Librarian II, Preservation Officer. The position is responsible for the planning, implementation and administration of a comprehensive conservation/preservation program for the UMCP Libraries, encompassing all aspects of materials treatment. The Preservation Officer will work with a core group of bibliographers and reference librarian selectors.

Qualifications: Required: MLS from ALA-accredited program and advanced training in book conservation/preservation; or equivalent professional degree and experience in the conservation/preservation field. Four years minimum progressively responsible experience in an academic or research library, at least two of which must have been at the managerial level. Extensive experience in the treatment of library materials and comprehensive knowledge of preservation issues. Demonstrated ability to plan and carry out a conservation/preservation program, working with both faculty and library staff in the accomplishment thereof. Salary: $\$ 28,700$ minimum. Salary commensurate with experience. Excellent benefits.

For full consideration, submit resume and names/addresses of 3 references by December 31, 1986, to:

\section{Virginia Sojdehei \\ Personnel Librarian \\ McKeldin Library \\ University of Maryland \\ College Park, MD 20742}


DIRECTOR OF THE LIBRARY, position available July 1, 1987. Position has responsibility for the overali operation and management of the university lıbrary in six (6) primary areas: 1) building collection resources appropriate to the needs and direction of the university; 2 ) administering library budget; 3 ) planning for and implementing library automation and systems; 4) providing long-term planning and evaluation of present services; 5) organizing staff responsibilities and 6) cooperating with other institutions. Requirements: a doctorate in a relevant field. ALA-accredited MLS, and library administratıve experience. Salary range: $\$ 35,990-\$ 48,294$ based on qualifications and experience. Qualified applicants should send their resumes, a copy of their transcripts, and the names and phone numbers of three (3) references by January 16, 1987 to: Francis H. Norton, Chairperson, Director of the Library Search Committee, Old Main 308, Shipperısburg Unıversity, Shıppensburg. PA 17257 Shippensburg Unıversity is an Equal Opportunity, Affirmative Action Employer and encourages applicatıons from Women and Racial Minorities.

ENGINEERING LIBRARIAN-BIBLIOGRAPHER. Avallable Febru ary 2, 1987. Required: Master's degree from an ALA-accredited program: knowledge of science and engineering reference and bibliographic resources; course work or experience in online database searching. Desirable: Experience or academic preparation in the sciences or engineering; reading knowledge of a modern foreign language, preferably German or French; strong commitment to public service. Salary: \$17,496 minimum. dependent upon qualifications and experience. Benefits include State contribution to health in surance premiums, payment of 88 percent of Social Security premiums for the first $\$ 16,500$ of annual salary for a total of $\$ 965.00$ and 8.5 percent of annual salary contributed by the State for optional retirement programs. Location: The University of Texas at Arlington is located in the Dallas/Fort Worth metroplex. has a current enrollment of approximately 23.000, and offers 97 degrees, 18 at the Ph.D. level. The University of Texas at Arlington Libraries presently have approximately $1,076,500$ items in the collections and a staff of 100. Applications should include a resume and the names and ad dresses of three professional references. Considerations for the position will begin January 15, 1987. Applications should be addressed to: Chalr. Engineering Librarian-Bibliographer Search Committee, The University of Texas at Arlington, P.O. Box 19497 Arlington, TX 76019. The University of Texas at Arlington is an equal opportunity, affirmative action employer.

EXECUTIVE DIRECTOR. The Hill Reference Library, a privately en dowed business library which serves the business community and the general public, announces an openıng for the position of Executive Director. The position requires a master's degree in library science and a minimum of seven years management experience in cludıng budget plannıng and supervising staff and expenditures Experience in a corporate or a business library preferred. Position reports to the President of the Board of Trustees. Salary negotiable Send credentials and three letters of reference to: Paul Wittkopf, Search Committee, James J. Hill Reference Library. 80 West Fourth Street, Saint Paul, MN 55102. Application deadline January 20 1987.

HEAD OF AUDIOVISUAL SERVICES. Widener University, Ches ter. Pennsylvania. Administers the library's audiovisual, nonprint collections and services, acting as liaison with faculty using nonprint materials, representing the library's AV interests in consortia. Participates actively in reference services and collection development. Supervises AV support staff. Reports to Library Director. Qualifications Specialized knowledge of the use of non-print media in academic Ibraries. Ability to plan for an expansion of audiovisual services. Master's degree from an accredited library program, appropriate extensive professional experience, knowledge of applicable library technology. Advanced education in media, computer applications, additional degrees desirable. Minımum salary $\$ 22,000$. 12 month appointment initially as Assistant Librarian with library faculty benefits. Position open July 1,1987 . Send letter of application, resume and names of (3) three references before January 15, 1987 to: Theresa Taborsky. Director, Wolfgram Memorial Library, Widener University, Chester. PA 19063. Contact at Midwinter ALA possible. EO/AA.

HEAD OF REFERENCE AND RESOURCE SERVICES, C. V. Starr East Asian Library. Reporting to the East Asian Librarian, this position has administrative responsibility for reference and access services, and for assessment, development and preservation of Columbia's distinctive East Asian collection of over 500,000 volumes,
Library

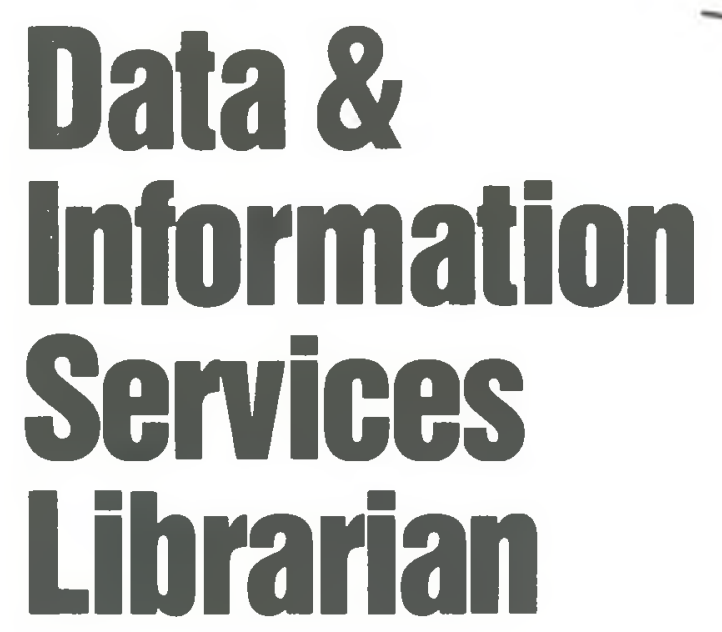

Stanford University Libraries seeks an individual to perform a leading role in planning and development of support services for "electronic scholarship". Coordinate program of automated services and on-line database searching. Participate as member of General Reference Dept. MLS or equivalent, knowledge of traditional and innoative reference services including automated information sources, technology and use, experience in database searching required.

Associate Librarian $(\$ 27,500$ $\$ 38,300)$ or Librarian $(\$ 31,300$ $\$ 46,300$ ) rank depending upon experience/qualifications. Send letter of application, resume and names of 3 professional references to Irene Yeh, Employment Coordinator, Stanford University Libraries, Stanford, CA $94305-6004$ by $1 / 1 / 87$. Cite \#292-CRLN , on all correspondence. An equal opportunity employer through affirmative action. 
mostly in Chınese, Japanese and Korean languages. Responsibilitıes include admınisterıng all reference and user services ıncludıng bıblıographıc instruction, database searchıng, cırculatıon, stack maintenance and resource sharıng programs; developıng new bıblıographıc tools and materials (print and online); providing direct reference service to library users: coordinating the activities of the three collection development/reference librarians in Chinese, Japanese and Korean language materials; and directly supervising collection development in Western language materials. The incumbent works closely with East Asian Studies students and faculty and cooperates with other library units, external networks and consortia. Qualifications are an accredited MLS or master's degree in East Asian studIes; knowledge of at least one East Asian language and excellent oral and written communicatıon skills in English; familiarity with bibliographic techniques and knowledge of research strategies for East Asian studies; and excellent managerial and interpersonal skills. Demonstrated leadershıp ability and experience with onlıne searchIng and innovative biblıographic instruction highly desirable. Salary ranges are: Librarian H: \$27,500-\$37,125: Librarian III: $\$ 30.500-\$ 44.225$. Excellent benefits include assistance with University housing and tuition exemption for self and family Submit resume listing three references to: Box 35. Butler Library, Columbia University, 535 West 114th Street, New York. NY 10027. Deadline for applications is February 1, 1987. An Affirmative Action/Equal Opportunity Employer.

HISTORY AND SOCIAL SCIENCES BIBLIOGRAPHER. New position. Under the direction of the Assistant University Librarian for Collection Development, responsible for the planning, development. and management of designated collections in history and other so- cial science subjects. Selects on British and European history: coordınates work with selectors responsıble for buılding collections in the history of other geographical areas; assumes responsibility for selecting on the history of other geographical areas as needed; depending on experience. interests and current staffing; assumes responsibility for selecting on other social science subjects: provides specialized reference and bıblıographic instructıon; works closely with faculty to establish collection priorities: provides advice on universıty collection management polıcy. Required qualificatıons: ALAaccredited graduate library degree; three to five years professional experience in a research library. with some responsibility for selectıon; knowledge of budgeting. acquisition of library materials, preservatıon issues and optıons: good communicatıon and management skills: workıng knowledge of European languages and the willingness to learn new languages as needed for collection development purposes: strong commitment to scholarship and collection development. Advanced degree In history and some knowledge of history beyond Europe preferred. Appointment will be made at the Librarian II level. Minimum salary for Librarıan II is $\$ 22.870$. Fringe benefits include 25 days paid vacation per year. TIAA/CREF retırement. Social Security. Blue Cross/Blue Shield and disability and major medical insurance. First consideration will be given to indıviduals whose applicatıon materials are received by 5 January 1987. Interested and qualified applicants should send letter of application. resume. and the names, addresses, and telephone numbers of 3 references to: William C. Sayre. Assistant University Librarian for Administrative Services. The University of lowa Libraries. Iowa City. IA 52242. The University of lowa is an equal opportunity, affirmative action employer

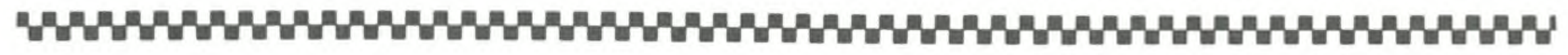 HEAD, SOCIAL SCIENCES AND HUMANITIES LIBRARY Michigan State University \\ (Librarian IV)
}

Reporting to the Deputy Director, this librarian has administrative/supervisory responsibility for the Social Sciences Humanities Library (including reference services and collection management and development), which includes the following units: Social Sciences/Humanities Reference, Humanities Collection Development, Social Sciences Collection Development, Africana, Agricultural Economics, Art, Business, Documents, Maps, Music, Planning and Design, Special Collections, and Urban Policy and Planning. Present staff includes 24 FTE librarians, 19 clerical support staff, and 25 FTE of student assistance.

Specific responsibilities include involvement with all departmental personnel activities; administration of collection management and development activities including managing a materials budget in excess of $\$ 1.5$ million; assume initiative in developing programs, policies, and procedures; provide the leadership, assistance and support required to enable the units to function effectively and efficiently; encourage the career development of individual staff members; maintain effective liaison with academic and other library departments; serve as an ex-officio member of the Library Advisory Council, as a member of the Director's Administrative Group, and on other committees as assigned; prepare reports as necessary; represent the library at meetings as required.

Minimum qualifications include an accredited graduate library degree, plus a graduate degree or degrees that indicate a wide knowledge of the resources and research processes within the social sciences and humanities; minimum of seven years of increasingly responsible research library experience; knowledge of research library programs, the research process, library automation, and research library public services and collection development programs; evidence of supervisory, organizational, and administrative ability; excellent communication skills, both oral and written; ability to work well with users at all levels, faculty, and staff; evidence of contributions in advancing library programs or publications resulting from research activities. Minimum salary: $\$ 35,000$. Position will remain open until filled.

Interested individuals should send a letter of application, a resume, and the names and addresses of three current references to:

\author{
Beth J. Shapiro \\ Deputy Director of Libraries \\ Michigan State University Libraries \\ East Lansing, MI 48824
}


HUNGARIAN CATALOGER. The Library of Congress has an Immediate openıng for a descriptive cataloger skilled in reading Hun garian. Master's degree in lıbrary science (or comparable lıbrary experience in catalogıng) and reading knowledge of a second foreign language are also required. Position has promotion potential to the GS 12 grade level. but will Initially be filled at the GS-9 $\$ 21.804-\$ 28$ 347 ) or GS-11 (\$26.381-\$34.292) grade level depending on applcant qualifications. Interested candidates should submit a Standard Form 171. Application for Federal Employment. by January 31 1987. 10: The Library of Congress. Employment Office. 101 Indepen dence Ave S.E. Room LM-107. Washington. DC 20540. Vacancy Announcement 60476. Application forms and copies of the vacancy announcement may be obtained by callıng (202) 287-5620 An Equal Opportunity Employer. H51212

LIBRARIAN. Dickınson College has an Immediate openıng for a be ginning hibrarian with training or experience in both technical and public services. This challenging position will require work in cataloging and reference as well as participation in biblıographic instruction. tialson with academic departments and collegial management in the context of a liberal arts educational program. ALA-accredited MLS and second master's in the liberal arts required. Mınımum salary
$\$ 22$ 000-\$24 000 Send letter of application vita, and three letters of recommendation to: Annette LeClair. Chairperson, Department o Library Resources. Dickınson College, Carlısie. PA 17013. Avallable immediately: final closing date February 1. 1987: will interview at ALA Midwinter. An affirmative action, equal opportunity employer.

LIBRARY DIRECTOR, University of Arkansas at Little Rock. Position reports to the Vice ChancelloriProvost. Requirements are an ALA-accredited MLS plus an additional advanced degree (preferably the doctorate): familiarity with a broad range of library functions gained through professsionai advancement; academic or research library administratıve experience, strong leadershıp, management. and communication skills: knowledge of OCLC and other automated systems: and a strong commitment to service. Position avallable summer. 1987 Tenure track with faculty rank and benefits. Salary range $\$ 4.5 .000$ to $\$ 60.000$. Send curriculum vitae and names with telephone numbers of three references by February 15, 1987, to James Parıns. Chair. Library Director Search Committee. Ot tenhelmer Library. University of Arkansas at Little Rock. Little Rock. AR 72204. The University of Arkansas at Little Rock is an affirmative action equal opportunity employer and actively seeks the candidacy of minorities and women

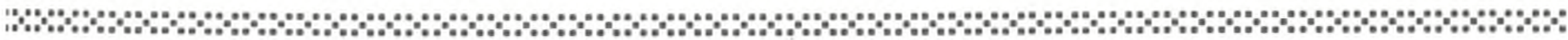

\section{REFERENCE SERVICES LIBRARIAN Trinity University}

Trinity University. San Antonio, Texas, invites applications for the position of Reference Services Librarian. a faculty appointment in a rapidly growing university library. Trinity, with 2,350 undergraduate and 350 graduate students, is strongly committed to excellence in the liberal arts and sciences tradition. Scholarly achievement is recognized through Phi Beta Kappa and other national honor societies. Selective admissions, highly qualified faculty, and outstanding teaching programs place Trinity among the excellent liberal arts and sciences universities in the nation. The Library has undertaken an accelerated program of collection development; presently the collection has some 550.000 volumes of books and bound periodicals (compared with 300,000 in 1980), plus sizable holdings of government documents, microforms, and nonprint items

The Reference Services Librarian will report to the Head of Reference. Primary responsibilities of the position are coordinating general reference services, including scheduling staff at reference desk and responsibility for reference collection development and management; providing reference desk service 10-15 hours per week: preparing bibliographic aids and library guides; faculty liaison work with some academic departments (preferably in the humanities and business), including collection development, user education and computer literature searching.

Qualifications include an appreciation for and commitment to undergraduate liberal arts and sciences education, initiative and creativity, interpersonal skills, the ability to function effectively in a complex organization, strong professional commitment, interest in research and publishing, and an ALA-accredited MLS. In addition. preference will be given to candidates with an academic background (preferably a graduate degree) in language, literature. philosophy, religion, fine arts, or business with relevant library experience, preferably in strong liberal arts and sciences institutions, and to those with a strong interest in and enthusiasm for user education and faculty liaison programs.

Instructor or Assistant Professor rank with faculty status, including tenure-track. Salary minimum \$19,500: twelve-month appointment; TIAA/CREF and usual fringe benefits. Send letter of application, de tailed resume. placement file if available, and names, addresses, and phone numbers of three references to:

\section{Richard Hume Werking \\ Director of Libraries \\ Maddux Library \\ Trinity University \\ 715 Stadium Drive \\ San Antonio, TX 78284}

We would prefer to receive applications by January 5, 1987, since we will be interviewing at ALA Midwinter, January 17-20: but applications will be accepted until January 23, 1987. 
LIBRARY SPECIALIST, LATIN AMERICAN LIBRARY SERVICES UNIT. University of Illinois at Urbana-Champaign. Under the general direction of the head of the Latın American Library Services Unit. position has responsibilities in cataloging, collection develop ment. and reference services responsibilities including: original cataloging (and authority work) of Latin American materials in the socia sciences and humanities; selection of materials in all relevant languages to support instruction and research in Latın American and Caribbean studies; provision of reference services and research and assistance in areas of collection responsibility. Also acts as a resource for other university library departments and collections in the Identification and processing of Latin American and Caribbean ma terials. Required qualifications: MLS from ALA-accredited school or equivalent. Excellent knowledge of Spanish. Evidence of ability to meet university standards of research, publication, and professional service for promotion and tenure. Preferred qualifications: degree in areas associated with Latin America and the Caribbean. Desired qualifications: working knowiedge of Portuguese and/or French. Familiarity with AACR2, LC subject headings, and Dewey Decimal classification system. Library experience with Latın American and Caribbean materials. Salary: $\$ 20.000$ upward: appointment at Assistant Professor level. Send letter of application and complete resume with names, addresses, and telephone numbers of 5 references to Nelly S. Gonzalez, Chair. Search Committee clo Library Personne Office. 127 Library. University of Illinois Library, 1408 W. Gregory Drive, Urbana, IL 61801; (217) 333-2786. Applicatıon and nomination deadline: 1/30/87. AA/EEO Employer

MANAGER, AUTOMATED CATALOGING. (Search Re-opened.) Manages program of 8 FTE support staff responsible for pre-order searching and verification, copy cataloging, OCLC input and all de partmental OCLC-related activities. Requires master's degree from an ALA-accredited library school, minimum of 2 years professiona cataloging experience. knowledge of MARC formats, LCSH. LC classification, AACR2, and automated cataloging systems. Supervisory experience preferred. Excellent oral and written communica tion skills and ability to interact effectively with all levels of staff essen.

10000000000000000000000000000

\section{SENIOR PROGRAM} OFFICER

\section{Research Libraries Group}

Primary responsibility for management of the RLG Collection Management and Development, as well as the Art and Architecture, Programs. Requires strong leadership skills and initiative. Works with RL.G committees, task forces, and central staff members on projects and policies designed to improve library user services and facilitate cooperative collection development and sharing of materials throughout the membership.

Qualifications: MLS and/or advanced degree in an academic discipline, 5 years professional experience in research libraries, experience with automated systems, demonstrated capacity for administration

Salary and benefits: Hiring range is $\$ 3,041-$ $\$ 3,947 /$ month. Stanford University benefits. Full job description upon request.

Send letter of application, resume and names of 3

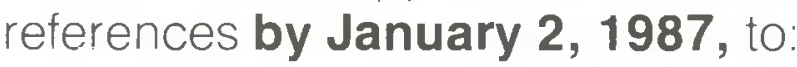

\author{
Kathy Davis \\ Human Resources Manager \\ Research Libraries Group \\ Jordan Quad \\ Stanford, CA 94305
}

0000000000000000000000000000 tial. Salary in lower \$20s depending on qualifications and experience. Excellent benefits package: choice of retirement programs: no state or local income tax. The University of Houston Libraries holdings exceed 1.4 million volumes, with a current materials budget of $\$ 2.6$ million. Total staff exceeds 250 . The Library is a mem. ber of ARL. Applications will be accepted until January 31, 1987. or until position is filled. Send letter of application, names of 3 references and resume to: Dana Rooks, Assistant Director for Administra. tion, University of Houston Libraries, 4800 Calhoun. Houston, TX 77004. Preliminary interviews at ALA Midwinter may be arranged. Equal Opportunity Employer

MANUSCRIPTS LIBRARIAN. Responsible for organizing and cat aloging manuscripts and folk.life archives regional materials. Faculty rank in the Department of Library Special Collections. Reports to Manuscripts and Archives Supervisor MLS from ALA-accredited program required, second graduate degree in American History, folkife studies or English preferred: experience in manuscripts work. knowledge of Kentucky history and familiarity with online library sys. tems desirable (particularly NOTIS and US MARC-AMC). Minimum salary $\$ 17.000$, with excellent benefits. Send letter of application, resume and names and telephone numbers of three references by January 15, 1987, to: Office of Academic Affairs, Library Search. Western Kentucky Unıversity. Bowling Green, KY 42101. An Affirmative Action, Equal Opportunity Employer

MONOGRAPHS DEPARTMENT HEAD (new position). Administer department of three professional and six support staff responsible for the purchase of monographs, the approval plan, original cataloging of monographs and media catalog filing. bibliographic hoiding rec. ords. and gifts; coordinate collection development activities and monitor fund allocations; assist in planning for online catalog. Qualificatıons: MLS from an ALA-accredited school; five or more years in cataloging or acquisitions, including experience with acquistions of mionographs and automated cataloging systems (preferably OCLC) two or more years supervisory experience. Faculty rank and status. 12-month contract. tenure-track with liberal fringe benefits. Salary about $\$ 30.000$ depending upon qualifications. Send resume and names of at least three references before January 15, 1987 to: Alan D. Hogan, Charperson of Search Committee, William S. Carlson Li. brary. The University of Toledo. Toledo, $\mathrm{OH} 43606$. The University of Tcledo is an Equal Opportunity. Affirmative Action Employer

MUSIC PUBLIC SERVICES LIBRARIAN, Northwestern University Library (Search reopened). Administers Music Library public services. Including reference. circulation, reserve, and stack control Supervises one library assistant and 16 student assistants. Serves as principal reference librarian. Responsible for book/periodical collection management. Edits NU Quarter Notes. Responsible for exhibits. Compiles user guides, bibliographies, and indexes. Qualficatıons: MLS from ALA-accredited library school, master's degree in music. preferably music history, required. Minimum of 2 years professional music library experience, including reference services, preferred Working knowledge of an online hibrary system desired. Demonstrated managerial and communication skills. Reading knowledge of German and French required. Broad knowledge of music literature and repertory. Salary: $\$ 19,000-\$ 25,000$. Send letter of application and resume, including names of three references, by January 15 1987. to: Lance Query. Assistant University Librarian for Planning and Personnel. Northwestern University Library. 1935 Sheridan Road, Evanston, IL 60201. AA/EOE

PHYSICS/ASTRONOMY LIBRARIAN. University of Illinols a Urbana-Champaign. Search deadline has been extended to January 16, 1987. (See C\&RL News, October 1986 p 625.) Complete job description mailed upon request. Contact: Allen G. Dries. Library Personnel Manager, University of Illinois Library, 127 Library, 1408 W. Gregory Drive., Urbana, IL 61801; (217) 333-8168 AA/EEO Employer

PRESERVATION FIELD SERVICE OFFICER. Northeast Docu ment Conservation Center seeks individual to provide conservation surveys, workshops, and disaster assistance for museums, libraries and historical organizatıons. MLS and collections management ex perience desired. Starting salary mid- to upper $\$ 20$ s. Application deadline December 31, 1986. Send resume, indicating present salary, and writing sample to: NEDCC, 24 School St. Andover. MA 01810. NEDCC is an affirmative action employer

PROJECT DIRECTOR, Retrospective Conversion and On-Line Systems. MLS required. Responsible for planning, coordinating and 
implementıng the retrospective conversion of biblıgraphıc records (approximately 200,000) and for participation in planning for an au. tomated ilbrary system. Experience with OCLC retrospective conversion and online systems required. Experience with bibliographic instruction and/or workshop presentation recommended. Responsible to director. Twelve month faculty position. Salary $\$ 18.000-\$ 21.000$. commensurate with education. experience. Application deadine December 31. 1986. Send letter. resume and three references to: Mary Anne Fedrick. Director of Library. Mary wood College 2300 Adams Ave Scranton. PA 18509. AA/EOE

REFERENCE/DOCUMENTS LIBRARIAN. Frankin and Marshall College. Lancaster. Pennsylvania Avallable immediately. With other meinbers of the reference department. serves at the reference desk. works with the bibliographic instruction program. conducts online searcnes. and participates in the library's collection development program. Responsible for all aspects of the U.S. Documents coilec tion (partial depository since 1895) including supervision of support staff and students. Qualıficatıons: ALA-accredited MLS. experience with government documents and online searching. Preferred BA the humanities or social sciences, experience with library automation and microcomputer applicatıons to library systems. Subject master highly desırable. Salary range in low \$20s. Applicatıon deadine: De cember 20, 1986. Please forward letter of apolicatıon, resume tran scripts, names and telephone numbers of three references to: Eliza beth Stegner. Franklın and Marshall College. P.O. Box 3003 Lancaster. PA 17604-3003. An Equal Opportunity Employer

REFERENCE LIBRARIAN. Duties Include general reference ser vice online biblıographic searching. biblıographic instruction. col lection development. Some weekend and evening duty required Requirements: graduate degree from ALA-accredited Institution. strong interest in public service excellent communicatıons skills. Desirable: some academic library experience. science background Faculty status, 23 days annual leave. usual fringes. Beginnıng sal ary: $\$ 18.000$. Please send letter of application. with resume includ ing three references, to. Sue Hiatt. Chalr. Search Committee for Ref erence Librarian. William Madison Randall Library. University o North Carolına at Wilmington, 601 S College Road. Wilmington. NC 28403-3297. Closing date: January 15. 1987. Affirmative Action. Equal Opportunity Employer

\section{THREE POSITIONS \\ Baylor University}

Three positions available immediately, Moody Memorial Library, Baylor University, Waco, Texas. Assistant Librarian, Documents Librarian, Reference Librarian with Science Emphasis. Baylor University is a privately supported denominational University with 11,500 students and faculty/student ratio of 1:20 located in Waco, Texas, a city of about 104.000, halfway between Dallas and Austin on I-35. Excellent fringe benefits include retirement, health, dental, 20 days vacation, faculty rank and status, tenure track. Preference given to applications received before December 31, 1986. Send letter of application, resume, and names and telephone numbers of 3 current references, to appropriate search committee chair. An equal opportunity employer.

ASSISTANT LIBRARIAN, Moody Memorial Library. Major responsibilities: Participates with Librarian in the planning, implementation, and coordination of library services provided by the central library; acts as library administrator in the absence of Librarian; manages personnel activities pertaining to non-faculty positions; Oversees maintenance of physical plant; works with Librarian in preparation and implementation of budget. Qualifications: ALA-accredited master's degree with three years of progressively responsible experience, preferably academic. 1-2 years in a supervisory position preferred. Effective communication and interpersonal skills; managerial experience; library automation experience preferred. Position available at Instructor or Assistant Professor level, dependent upon experience and qualifications. Salary: minimum at Instructor level \$21,000 for 12 months. Correspond with: Margaret Hughes, Chair. Assistant Librarian Search Committee. Moody Memorial Library, Box 6307, Waco. TX 76706-0307

DOCUMENTS LIBRARIAN, Moody Memorial Library. Seeking service-oriented, enthusiastic, energetic librarian to manage a partial depository of 900,000 federal documents (print and microforms) and USGS DMA, and PAIGH maps. Supervises 3 support staff and 2.5 FTE student assistants. Provides documents reference service (including DIALOG searching) and extensive bibliographic instruction. Qualifications ALA-accredited master's with minimum of three years professional documents experience; proven leadership ability; good public relations and communication skills. Salary minimum $\$ 22,200$ for 12 months Assdstant Professor. Correspond with: Avery T. Sharp, Chair, Documents Librarian Search Committee Moody Memorial Library, Box 6307, Waco. TX 76706-0307.

REFERENCE LIBRARIAN, SCIENCE EMPHASIS, Moody Memorial Library. Seeking to fill a new position with an experienced reference librarian with strengths in science information. Centralized reference department has six professionals. Major responsibilities: general reference service, including desk coverage (with regular evening and weekend hours); database searching and bibliographic instruction; supervision and training of reference desk students; supervision of microform service. Qualifications: ALA accredited master's with two years of professional reference service; supervisory experience; experience with bibliographic instruction; demonstrated aptitude for working with machines; ability to communicate effectively. Desired qualifications: strong academic background in science or experience in using science materials in public service: knowledge of database searching. Position available at Instructor or Assistant Professor level, dependent upon experience and qualifications. Salary: minimum at Instructor level $\$ 20.400$ for 12 months. Correspond with: Janet Sheets, Chair, Reference Librarian Search Committee. Moody Memorial Library, Box 6307, Waco, TX 76706-0307. 
REFERENCE LIBRARIAN. This Assistant Reference Librarian position is responsible for professional reference service evenings and weekends in a busy urban unıversity library with a diverse clientele. Database searchıng, library user instruction. collection development are other dimensions of this position. Faculty rank and status, 12 . month contract, tenure track with liberal fringe benefits. Salary is $\$ 20.000$ depending upon qualifications. We are seeking an experienced reference librarian (1-2 years) with an ALA-accredited MLS or appropriate advanced degree. Experience in database searching is desirable. Send resume and names of at least three references before January 20,1987 to: Kathleen Voigt, Chairperson of Search Committee. William S. Carlson Library. The University of Toledo. Toledo. $\mathrm{OH} 43606$. The University of Toledo is an Equal Opportunity. Affirmative Action Employer

REFERENCE LIBRARIANS. Two Science specialists; one Social Science specialıst. The LSU Libraries Reference Services Division has 10 librarians and 10 FTE support staff. The tenure track professional positions report to the Head of Reference Services. Specific responsibilities include desk service, onlıne searchıng, bıblıographic instruction, and collection development. Each position requires the ALA-accredited MLS; degrees in the appropriate subject areas (pure and applied sciences; a social science discipline) or equivalent library experience. Reference experience preferred but not required. Salary negotiable: $\$ 19,000$ minimum. Excellent benefits. Review of applications will begin February 2, 1987. Send letter of application. resume, names, addresses and phone numbers of at least three references to: Sharon A. Hogan. Director of Libraries. Middleton Library, Louisiana State University, Baton Rouge, LA 70803. LSU is an equal opportunity university.

SCIENCE \& TECHNOLOGY LIBRARIAN. Collection Development and Reference assignments. Liaison with faculty. Service to area business and industry. Online searching. Undergraduate degree in science/technology and MLS from ALA-accredited library school required. Second master's in science/technology and at least 2 years experience in publıc services in academic library preferred. Salary. Libiarian IV. from \$23.276: Librarian III. from \$28.566. depending on qualifications and experience. Tenure-track, 12-month position. Recruitment will remain open until position is filled. Submit letter of application, resume, and names of 3 references to: Judith L. Hunt University Librarian. University of Bridgeport. Wahlstrom Library. 126 Park Avenue. Bridgeport. CT 06601. An equal opportunity em ployer

SERIALS LIBRARIAN. San Francisco State University seeks a II brarian to assume responsibility for original, adaptive and copy cataloging of serials including new serial titles. continuations, and added volumes in all formats; for coordınation of University theses catalogIng, binding. microfichıng; and for resolving/coordinating serials IS sues and cataloging throughout Technical Services, including biblıgraphic control of serials. May include responsibility for direction coordination of all biblıographic control aspects of continuations standıng orders, added volumes and periodicals. Permanent. tenure-track position. Appointment date: April 1, 1987. Qualifica tions: Required: MLS from ALA-accredited institution: minımum of three years experience as a professional. of which minimum of two years must be in serials with an emphasis on serials cataloging: ex perience in automated cataloging systems such as OCLC; working knowledge and familiarity with AACR2 and LC cataloging practice and authority forms; demonstrated oral and written communication intergroup and organizatıonal skills. with ability to work effectively with faculty and staff: ability to problem solve, exercise initiatıve and judgement, and to be flexible. Preferred qualifications: Experience in developing operational procedures, training and developing sup port staff to work in an online cataloging environment; having knowl edge of serials cataloging and serials issues to direct and coordinate all bibliographic control aspects of continuations, standing orders added volumes, periodicals; experience in plannıng and implement ing an online serials processing system. Appointment level: Senior Assistant or Associate, depending on qualifications. Salary range: $\$ 29,640$ - \$45.096. Benefits: 24 days vacatıon; liberal Unıversity paid benefits. To apply send letter of application, resume, and names, ad dresses and telephone numbers of 3 references by January 15 1987, to: Eloise McQuown. Assistant Director, Library. San Fran. cisco State University, 1630 Holloway Ave.. San Francisco. CA 94132. AAE/EOE

SOCIAL SCIENCE REFERENCE LIBRARIAN/BIBLIOGRAPHER. Responsible for the Library's collectıon development in assigned social science disciplines. Provides service at the Informa tion Desk, including some weekend and evening hours. Participates in an active program of library instruction and computerized data base searchıng in the disciplines of selection responsibility. Requires a Master's degree from an ALA-accredited library school. Undergraduate degree in a social science disciplıne or reference experı ence highly desirable. $\$ 17.000$ minimum salary depending on qualificatıons. Excellent benefits includıng choice of retırement programs The University of Houston Libraries have 1.4 million volumes, a ma terials budget of $\$ 2.6$ million, and a total staff of 250 . The Library is a member of ARL. To ensure consideration, applications must be re celved by January 31, 1987. Send letter of application, names of 3 references, and resume to: Dana Rooks. Assistant Director for Administration, University of Houston Librarıes. 4800 Calhoun. Hous ton, TX 77004. Prelimınary interviews at ALA Midwinter may be ar ranged. Equal Opportunity Employer

\section{SOUTH ASIA/SOUTHEAST ASIA BIBLIOGRAPHER AND SO-} CIAL SCIENCES REFERENCE LIBRARIAN. Search Reopened Responsible for meeting the information needs of faculty and students of South and Southeast Asia and for providing consultatıon reference service and bibliographic instruction to social science faculty and students. Reporting to the Assistant Director for Resource De velopment on the overall development and assessment of research collections in the major indigenous languages of northern India Pakistan. Nepal. Bangladesh and Tibet Supervision of precataloging processing of materials recelved on the PL-480 program providing advice on preservation needs of South and Southeast Asıa materials. coordination of collection development with other libraries in the Research Libraries Group. Reporting to the Assistant Director for Social Sciences for duties comprised primarily of in-depth reference services including consultations by appointment and preparation of guides, etc., bibliographic instruction and end user training Qualifications are subject expertise and scholarly research exper. ence equivalent to at least a master's level in a social science or area studies program; language skills equivalent to at least three years of study of a devanaugirı language such as Sanskrit. Pali or Prakrit: abı. ity to communicate effectively orally and in writıng: flexibility and cre ativity to work with colleagues in a complex environment. A Ph. D. in a relevant field, an accredited MLS and some supervisory experience are desirable. Salary ranges are: Librarian I: $\$ 22.000-\$ 28.600$; LI brarian If: $\$ 24,000-\$ 32,400$. Excellent benefits include assistance with University housing and tuition exemption for self and family. Submit resume listing three references to: Box 35. Butler Library, Co lumbia University, 535 West 114th Street. New York. NY 10027 Deadline for applications is January 30. 1987. An Affirmative Action, Equal Opportunity Employer

\section{LATE JOB LISTINGS}

CATALOGING LIBRARIAN. Under the general direction of the Head of Bibliographic Control, to catalog library materials, primarily non-book material. ALA-accredited MLS required. Cataloging experience with OCLC desired but not required. Annual salary $\$ 17,250+$ depending upon experience; excellent fringe benefits. Available immediately. Send resume, transcripts (undergraduate and graduate), placement papers and two separate letters of recommendation to: George N. Hartje, Library Director, Pickler Memorial Library, Northeast Missouri State University, Kirksville, Mo 63501-0828. Deadline December 31,1986 . EOE/AA. 
CHIEF, ACQUISITIONS SERVICES (Announcement 86-554-F). Experienced librarian to manage unit of 15 staff responsible for ordering and receiving library materials, binding preparation, gifts and exchanges, and the serial record in support of 14 branches and other Smithsonian Institution offices. Administers annual budget of $\$ 1$ million, ensuring effective operation of fiscal controls and utilizing GEAC-based automatic acquisitions system. Reports to Assistant Director for Collections Management. Position open until filled; deadline for applications is January 5, 1987. Salary minimum $\$ 37,599$. For application information and forms, write: Employment office, Smithsonian Institution, Washington, DC 20560 or call (202) 357-2465. Specify Announcement Number. The Smithsonian Institution is an equal opportunity employer.

CHIEF, CENTRAL REFERENCE AND LOAN SERVICES, AND UNIT MANAGER, CENTRAL SERVICES UNIT (Announcement 86-556-F). Experienced librarian to administer central reference collection and services in support of 12 Smithsonian Institution Library branches and specialized Smithsonian activities (Smithsonian magazine, Smithsonian Institution Press, etc.). Also supervises the Museum Reference Center, the Museum Support Center, the ILL unit, and the SIL annex. Reports administratively to the Assistant Director for Research Services, and for collections-related functions to the Assistant Director for Collections Management. Position open until filled; deadline for applications is January 5, 1987. Salary minimum $\$ 37,599$. For application information and forms, write: Employment office, Smithsonian Institution, Washington, DC 20560 or call (202) 357-2465. Specify Announcement Number. The Smithsonian Institution is an equal opportunity employer.

CHIEF, NATIONAL AIR \& SPACE MUSEUM BRANCH, AND MANAGER, PHYSICAL SCIENCES UNIT (Announcement 86-555-F). Experienced librarian to administer collections and provide reference services in support of the staff of the National Air \& Space Museum, other Institution staff, the scholarly community and the general public. Also supervises the Smithsonian Astrophysical Observatory Branch Library, Cambridge, Massachusetts. Reports administratively to Assistant Director for Research Services and for collections-related functions to Assistant Director for Collections Management. Position open until filled; deadline for applications is January 5, 1987. Salary minimum $\$ 37,599$. For application information and forms, write: Employment office, Smithsonian Institution, Washington, DC 20560 or call (202) 357-2465. Specify Announcement Number. The Smithsonian Institution is an equal opportunity employer.

COORDINATOR FOR CIRCULATION AND INTERLIBRARY SERVICES, Rutgers University Libraries. Available: Immediately. Reporting to the Assistant University Librarian for Public Services, coordinates circulation services and develops policy and procedure recommendations for the online circulation system. Works closely with Technical Services and Systems personnel in solving problems, training and documentation. Administers interlibrary support services: intra-library loan, shipping and the library annex, and interlibrary loan activities including service to the New Jersey Library Network. MLS from an ALA-accredited library school and a minimum of four years public service experience in an academic, research or special library required. Administrative/supervisory experience desirable. Rutgers University Libraries serve some 50,000 students and 2,500 faculty on three campuses. Collections of over 3 million volumes are housed in 18 libraries. Rutgers is a member of the Research Libraries Group. Salary commensurate with experience with a minimum of $\$ 25,907$. Tenure track, calendar year appointment. TIAA/CREF, life/health insurance, 22 days vacation. Submit resumes and names of three references by January 1, 1987, to: Barbara E. Sanders-Harris, (APP 119), Personnel officer, Alexander Library, Rutgers University, New Brunswick, NJ 
DIRECTOR OF LIBRARIES, Marshall University (search reopened). Marshall University invites nominations of and applications from dynamic and creative individuals for the position of Director of Libraries. The Director reports to the Vice President for Academic Affairs and administers the James E. Morrow Library, the Health Sciences Library, and the Music Library. The Director also oversees all University special collections. The library system has a collection of approximately 365,000 bound volumes and other extensive holdings. It serves a student body of approximately 12,000 graduate and undergraduate students in nine divisions: College of Business, College of Education, College of Fine Arts, College of Liberal Arts, College of Science, Community College, Graduate School, School of Medicine, and School of Nursing. Marshall University is a progressive, mission oriented state university with innovative programs such as the Society of Yeager Scholars, that will depend heavily on the development and direction given by the Library. Support for research is a major concern of the Director, as is physical plant development. Candidates must hold an MLS from an ALA-accredited institution. An earned doctorate is highly desirable. The following attributes are also essential: (1) substantial professional experience in academic libraries with evidence of increasing and successful administrative responsibility; (2) sound knowledge of and experience in automated systems and services; (3) experience in bibliographic control and management, resource sharing, and academic budgeting; (4) evidence of professional and scholarly achievement; and (5) effective communication skills. The salary will be commensurate with qualifications and experience. Nominations and applications will be reviewed beginning January 1, 1987. They will be received until an appointment is made. Applications must include a resume and three current letters of reference. References will be treated in a confidential manner and will not be contacted until advanced stages of the screening process. Position is to be filled no later than July 1, 1987. Nominations and applications should be sent to: Office of Academic Affairs, Marshall University, Huntington, WV 25701 .

DIRECTOR OF LIBRARIES, University of Northern Colorado. The Director is the chief administrator of Libraries and the Educational Materials Services, a member of the University Cabinet, and reports to the Vice President for Academic Affairs. Qualifications: Required is MLS from an ALA-accredited institution and an advanced degree in an academic or professional discipline; possession of a record of successful innovation; and demonstrated knowledge and/or experience of public and technical services, new technologies, and communication skills. Academic library administrative experience is required, minimum 5 years preferred. Non-administrative professional library experience also is required, minimum 2 years preferred. Candidates also should have held progressively more responsible administrative positions in an academic or research library and demonstrated evidence of continuing commitment to scholarly publication and professional development. Full position description is available on request. 12-month salary; $\$ 43,000$ minimum, depending on qualifications and experience. Position available July 1, 1987. Appications accepted until January 16, 1987. Send applications, resume, and names/ addresses/phone numbers of 3 references to: Ron Edgerton, Chair, Director of Libraries Search Committee, c/o Academic Affairs, University of Northern Colorado, Greeley, CO 80639. The University is an AA/EO employer.

HEAD, INTERLIBRARY SERVICES DEPARTMENT. Texas A\&M University. Supervise and manage on-going program of interlibrary services including borrowing, lending, bibliographic verification, and materials location. Manage USDA Regional Document Delivery Service through coordination of participating libraries, 
submission of statistics for region, and provision of materials to USDA personnel. Serve as Acting Head, Circulation Division, in absence of Head. Qualifications: ALA-MLS. Two years post-MLS library experience. Professional or preprofessional ILS or related OCLC bibliographic search experience required; supervisory public services experience preferred. Salary: Minimum $\$ 19,000$ for 10.5 months; negotiable. Closing date: To ensure full consideration, applications for all positions should be received by January 15, 1987. Applicants should submit a letter of application, complete resume, and names and telephone numbers of three professional references. Benefits: Competitive benefits package. No state income tax. Faculty rank. For complete description of duties, qualifications and benefits, and to apply, call or write: Gloriana St. Clair, Acting Head, Personnel Operations, Evans Library, Texas A\&M University, College Station, TX 77843; (409) 845-8111. AA/EEO Employer.

HEAD, MONOGRAPH PROCESSING DIVISION, University of Cincinnati. New Position. Search reopened. The University of Cincinnati Libraries are seeking applications for the management position of the Head, Monograph Processing Division. It will be the responsibility of the person in the position to merge the monograph cataloging operations and bibliographic functions of Acquisitions to form the new Division. The Head will be responsible for the management of the centralized monograph processing services of the University Libraries and for the maintenance of bibliographic and holdings records in the online catalog. The University of Cincinnati Libraries are a member of OCLC and have installed an online catalog (UCLID). The database contains 750,000 records, representing the holdings of the five library jurisdictions of U.C. Conversion of holdings is ongoing. The person in the position will have a major role in facilitating the transition from a manual to an online environment. This is an excellent opportunity for the experienced librarian to develop a new organizational reporting structure and workflow. The Head, Monograph Processing supervises a staff of approximately 30, including 6 librarians, and reports to the Associate University Librarian for Access Services. Qualifications: Master's degree in library science from an ALA-accredited program. Demonstrated leadership, management and human relations skills and successful supervisory experience. Five years progressively responsible professional experience in a large academic or research library, including substantial experience in some area of monograph processing. Some public service experience highly desirable. Demonstrated understanding of contemporary cataloging rules and procedures and their application in an online environment. Experience with OCLC. Ability to communicate clearly, both orally and in writing. Minimum salary: $\$ 30,000$, depending on qualifications and experience. Available immediately. Send resume and names of three references by January 16, 1987, to: Sharon Tuffendsam, University Libraries Personnel officer, 640 Langsam Library, University of Cincinnati, Cincinnati, $\mathrm{OH}$ 45221-0033.

HEAD, MUSIC LIBRARY. University of California, Berkeley. Responsible for development and management of collections, space, services, fund raising and personnel. Engage in professional and research activities, participate in planning and policy development of the General Library, and maintain communication and liaison with the Department of Music. MLS and substantial educational background in musicology. Candidate lacking the MLS degree will be expected to secure one within 2-4 years. Administrative and supervisory experience in academic or research music library. Experience with automation and bibliographic control of music, knowledge of cooperative resource sharing, and techniques of bibliographic instruction and online database searching are desirable. May entail part-time teaching in Department of Music if qualifications are appropriate. Full job description on request. Appointment 
salary range $\$ 39,456-\$ 45,084$ per annum. Open until filled; candidates applying by January 5, 1987 will be given first consideration. Send resume, including names and addresses of three professional references to: William E. Wenz, Room 447 General Library, University of California, Berkeley CA 94720 . EEO Employer.

HEAD OF TECHNICAL SERVICES (Search reopened). Faculty, tenure-track position, Assistant professor level. Supervise cataloging and acquisitions; serve as library liaison to some academic disciplines and regional network; perform some online database searches; recommend policy/procedural modifications; some reference desk work, including evening and weekend rotation. Qualifications: ALA-Accredited Master's degree; knowledge of library operations with special emphasis on descriptive and subject cataloging utilizing AACR2, LCSH and LC classification, MARC formats, OCLC, and ALA (1980) filing rules; supervisory experience required. Second master's degree, 3-5 years of directly related professional experience desired. Salary from $\$ 20,000$, depending on experience and qualifications. Send letter of application, complete resume, and all library positions held, naming (with addresses and phone numbers) immediate supervisors, plus 3 other references and graduate transcripts by January 1 , 1987, to: Gaynelle Pratt, Personnel Office, Keene State College, Keene, NH 03431. Please note in letter if available at ALA Midwinter. AA/FOE.

HEAD, SERIALS SERVICES DEPARTMENT (anticipated). Reports to the Associate Director for Technical Services and is responsible for general administration and supervision of the Serials Services Department and its staff. Major departmental functions include serials acquisitions; serials control; public service access to serials information; housing of 7,000+ current serials; binding, end processing and minor repair of Library materials; public service access to newspapers and microforms. Required: ALA-accredited MLS; minimum of three years of responsible and appropriate professional experience, preferably in a research library; proven supervisory ability; ability to communicate effectively orally and in writing; ability to work independently. Preferred: Strong background in serials processing, OCLC, AACR2, and public service; knowledge of foreign languages; familiarity with NOTIS serial control system. Salary: Dependent upon qualifications, experience and rank; $\$ 28,000$ minimum. Benefits: Equivalent faculty status and tenure track; generous leave benefits; optional insurances; State Teacher's Retirement System. Review of applications will begin February 2, 1987. Apply to: Sharon A. Hogan, Director of Libraries, Middleton Library, Louisiana State University, Baton Rouge, LA 70803. LSU is an Equal Opportunity University.

HUMANITIES LIBRARIAN. University of California, Berkeley. Manage and develop English language humanities collections and serve as Library liaison with faculty and graduate students. Select current and retrospective materials, provide reference service and bibliographic instruction to users of the English languages collections. Participate in and initiate library instructional and orientation programs. Requires MLS degree and graduate work (advanced degree desirable) in Humanities discipline with strung background in English or American Literature collection development and general reference desk experience in a medium-large academic research library; knowledge of recent advances in literary scholarship and current developments in research libraries. Experience in bibliographic instruction, and experience with automated systems of bibliographic retrieval desirable. Full job description on request. Appointment salary range $\$ 29,340$ to $\$ 34,452$ per annum. Open until filled; candidates applying by January 5, 1987 will be given first consideration. Send resume, including names and addresses of three professional references to: William E. Wenz, Room 447 General Library, University of California, Berkeley CA 94720. EEO Employer. 
LIBRARY DIRECTOR, Stetson Memorial Library, Mercer University. Mercer University invites applications and nominations for director of the Stetson Library on the Macon campus. Mercer is a comprehensive, coeducational, private university affiliated with the Georgia Baptist Convention. With 6,300 students on four campuses, ilercer offers traditional undergraduate programs and graduate programs in medicine, law, pharmacy, business, education, and engineering. Stetson Library, one of five Mercer Libraries, serves the College of Liberal Arts, School of Business and Economics, and School of Engineering. Stetson Library, a member of OCLC and SOLINET, houses 200,000 bound volumes and 1,100 current periodical titles. The library offers bibliographic instruction and DIALOG searches and is a selective depository for federal government documents. Conversion to LC classification and retrospective conversion are well underway, anticipating moving into a new 94,875 square foot building by December 1988, with an automated, integrated library system. The Director of Stetson library reports to the Assistant Provost for Instructional Resources, manages an operating budget of $\$ 600,000$, and oversees a staff of five professionals and eleven support staff. The Director is expected to plan and administer progressive, effective library programs. The Director serves on college and university committees and is an active participant in governance and policy decisions affecting the Library. The successful candidate will have an understanding of and commitment to liberal and professional education and to the teaching role of the Library. Applicants should have at least seven years of varied experience in academic libraries, including some administrative experience (program development, evaluation, personnel, budgets). Strong leadership skills and professional identity must be linked with a service orientation. An accredited MLS degree is required; advanced degree(s) are strongly preferred. The position is a nontenured faculty appointment, 12 months; the salary range is $\$ 35,000-\$ 45,000$ depending on experience and qualifications. The University offers competitive benefits packages. Preliminary interviews, ALA Midwinter. Appointment is expected to begin July 1, 1987. Applicants should submit a letter, vita, and complete information on at least five references by January 15, 1987, to: Marjorie T. Davis, Assistant Provost for Instructional Resources, Mercer University, Macon, GA 31207. Mercer University is an AA/EEO employer.

ORIGINAL CATALOGER, MICROFORM MATERIALS (entry leve1; search extended). Texas A\&M University. Responsible for cataloging and classifying monographic materials in all languages, subjects, and formats including primary responsibility for monographic microform materials. Duties include creation of original cataloging and review of subject headings, classification, and descriptive cataloging on OCLC cooperative copy. Qualifications: ALA-MLS. Prefer pre-professional monographic cataloging experience with AACR2 and LC classification and subject headings. Salary: $\$ 17,000$ for 10.5 months; $\$ 18,000$ with additional Master's degree. Closing date: To ensure full consideration, applications for all positions should be received by January 15, 1987. Applicants should submit a letter of application, complete resume, and names and telephone numbers of three professional references. Benefits: Competitive benefits package. No state income tax. Faculty rank. For complete description of duties, qualifications and benefits, and to apply, call or write: Gloriana St. Clair, Acting Head, Personnel Operations, Evans Library, Texas A\&M University, College Station, TX 77843; (409) 845-8111. AA/EEO Employer.

REFERENCE/GOVERNMENT DOCUMENTS LIBRARIAN (Search reopened). Stetson Library, Mercer University, seeks public-service oriented librarian to administer government documents and work in general reference. Mercer is a comprehensive, coeducational, private university affiliated with the Georgia Baptist Convention, with an enrollment of 6,300 on four campuses. Stetson 
Library on the Macon campus serves Liberal Arts, Business, and Engineering and is a selective depository for U.S documents. Move into the new 94,875 square foot building slated for December 1988. This 1ibrarian, one of six professionals and eleven support staff, supervises documents (collection evaluation, processing, student assistants), assists with reference, conducts online searches and bibliographic instruction. Committee assignments and faculty liaison activities expected. Some night and weekend work required. Qualifications: Accredited MLS and academic library experience required. Demonstrated interest in documents and bibliographic instruction; reference and online search experience preferred. Initiative, good communication and interpersonal skills necessary. Nontenure track 12 month faculty appointment, competitive benefits. Salary $\$ 19,000-\$ 24,000$ depending on qualifications and experience. Send letter, resume, and complete information on three references by December 20, 1986, to: Elizabeth D. Hammond, Acting Director, Stetson Library, Mercer University, Macon, GA 31207. Mercer is an AA/EEO employer.

REFERENCE LIBRARIAN. 9-month tenure track position, with faculty rank and status. Required: MLS from ALA-accredited library school, demonstrated communications and teaching skills. Desirable: subject masters and/or background in business or economics, 2-3 years experience in an academic library and experience with OCLC and/or database searching. Duties: general reference, including one weeknight and occasional academic vacation periods, library instruction, possible database searching, some book selection. Position available August 24, 1987. Salary $\$ 20,500$, depending on qualifications. Herrick Memorial Library is the University Library serving the Colleges of Liberal Arts \& Sciences, Nursing, Business and Administration and Graduate Education, with a student body of approximately 2,000. Library staff consists of 6 professionals, 3 technical specialists, 12 support staff and student aides. Send letter of application, resume and 3 recent references by February 1, 1987, to: June E. Brown, University Librarian, Herrick Memorial Library, Alfred University, Alfred, NY 14802. Alfred University is an Affirmative Action, Equal Opportunity Employer.

REFERENCE LIBRARIAN. Under the general direction of Head Reference Librarian to use formal and informal skills in library instruction, teaching basic course in use of library, to perform database searching, as well as customary reference services to a student body of 6,500. ALA-accredited MLS required; reference experience desirable but not required. Annual salary $\$ 17,250+$ depending upon experience; excellent fringe benefits. Available immediately. Send resume, transcripts (undergraduate and graduate), placement papers, and two separate letters of recommendation to: George N. Hartje, Library Director, Pickler Memorial Library, Northeast Missouri State University, Kirksville, MO 63501-0828 • EOE/AA. Deadline December 31, 1986.

REFERENCE LIBRARIAN, University of Georgia Libraries. One entry-level position. (Salary minimum $\$ 17,200 \bullet$ ) Recent graduates may have the opportunity to participate in a special staff development program funded by the Council on Library Resources. Duties: Reference Librarians in the Science Library are responsible for providing reference, instructional, and referral services and for developing the Science Library collection in assigned areas. Reference duties involve assisting students, faculty and staff in making effective use of library resources, including government documents and science databases. The Science Library serves the biomedical, agricultural, and physical sciences. The 76,000 square foot facility has 500,000 volumes and 5,500 current journal subscriptions with a staff of 28 . Qualifications: ALA-accredited MLS; working knowledge of basic reference sources; knowledge of database searching; effective oral and written communication skills; ability to establish and maintain effective working 
relationships; interest in science literature desired; ability to work with a foreign language desired; strong interest in academic librarianship desired. Application procedure: Send letter of application by January 9, 1987, including resume and names of three references to: Florence King, Administrative Office, Main Library, University of Georgia Libraries, Athens, GA 30602. This position will be filled only if suitable applicants are found. An Equal Opportunity, Affirmative Action Institution.

REFFRENCE LIBRARIAN, HUMANITIES (entry level). Texas A\&M University. Provides comprehensive reference assistance in the Reference Department with emphasis on the Humanities; includes assisting patrons in formulating search strategies and locating needed information through indexes and other reference tools, as well as through computer searching. Acts as division liaison with English, Modern Languages, and Psychology Departments. Assists with bibliographic instruction. Qualifications: ALA-MLS. Subject background in the Humanities, preferably in English. Second Master's degree and some preprofessional experience desirable. Salary: Minimum $\$ 17,000$ for 10.5 months; $\$ 18,000$ with additional Master's degree. Closing date: To ensure full consideration, applications for all positions should be received by January 15, 1987. Applicants should submit a letter of application, complete resume, and names and telephone numbers of three professional references. Benefits: Competitive benefits package. No state income tax. Faculty rank. For complete description of duties, qualifications and benefits, and to apply, call or write: Gloriana St. Clair, Acting Head, Personnel Operations, Evans Library, Texas A\&M University, College Station, TX 77843; (409) 845-8111. AA/EEO Employer.

REFERENCE LIBRARIAN, SCIENCE AND TECHNOLOGY (entry level; search extended). Texas A\&M University. Provides comprehensive reference assistance with emphasis on the sciences from a centralized reference collection. Prepares bibliographies and guides to the literature for use in staff training and in classroom instruction. Assists with bibliographic instruction and computerized reference services. Serves as a Reference Division resource librarian in the sciences. Qualifications: ALA-MLS. Academic background in the sciences required, preferably in the physical or life sciences. A second master's degree in a science-related field or two years of pre-professional library experience preferred. Salary: $\$ 17,000$ for 10.5 months; $\$ 18,000$ with additional master's degree. Closing date: To ensure full consideration, applications for all positions should be received by January 15, 1987. Applicants should submit a letter of application, complete resume, and names and telephone numbers of three professional references. Benefits: Competitive benefits package. No state income tax. Faculty rank. For complete description of duties, qualifications and benefits, and to apply, call or write: Gloriana St. Clair, Acting Head, Personnel Operations, Evans Library, Texas A\&M University, College Station, TX 77843; (409) 845-8111. AA/EEO Employer.

REFERENCE LIBRARIAN, SOCIAL SCIENCES/EDUCATION (experienced). Texas A\&M University. As part of a dynamic and innovative Reference Division, provides comprehensive reference assistance with emphasis on education and the social sciences, from a centralized reference collection. Additional duties include preparation of bibliographies and guides to the literature for use in staff training and for use in classroom instruction and assistance with bibliographic instruction for students and faculty. Prepares a computerproduced index to the Curriculum Collection and assists with online database searching. Qualifications: ALA-MLS. Two years post-MLS library experience. Degree in education or two years teaching experience at elementary or secondary school level. Salary: Minimum $\$ 19,000$ for 10.5 months; negotiable. 
Closing date: To ensure full consideration, applications for all positions should be received by January 15, 1987. Applicants should submit a letter of application, complete resume, and names and telephone numbers of three professional references. Benefits: Competitive benefits package. No state income tax. Faculty rank. For complete description of duties, qualifications and benefits, and to apply, call or write: Gloriana St. Clair, Acting Head, Personnel Operations, Evans Library, Texas A\&M University, College Station, TX 77843; (409) 845-8111. AA/EEO employer.

REFERENCE LIBRARIAN/TECHNICAL SERVICES COORDINATOR. Mabel Smith Douglass Library, Rutgers University. Available: April 1, 1987. Provides reference service, including database searching, and participates in the bibliographic instruction program. Selects library materials in the social sciences and coordinates technical service functions in the library. MLS from ALA-accredited library school and at least four years of academic library experience (reference and technical services) are required. Advanced subject degree, scholarly record, foreign langauge competency, and collection development experience are desirable. Mabel Smith Douglass Library is one of four major libraries on the New Brunswick campus of Rutgers University. It is an undergraduate library of 150,000 monograph volumes and 1,200 serial titles with an emphasis on liberal arts, environmental studies, women's studies, and the performing arts. Tenure track, calendar year appointment. TIAA/CREF, life/health insurance, 22 days vacation. Salary commensurate with experience with a minimum of $\$ 25,907$. Submit resume and names of three references by January 1, 1987, to: Barbara E. Sanders-Harris, (APP 118), Personnel officer, Alexander Library, Rutgers University, New Brunswick, NJ 08903. An Equal Opportunity, Affirmative Action Employer.

UNIVERSITY LIBRARIAN, Jacksonville State University, Jacksonville, Alabama. Deadline for application January 19, 1987. Applications and nominations are invited for the position of University Librarian. The University Librarian has overall administrative responsibility of the Library and reports to the Vice President for Academic Affairs. The University Librarian is expected to perform the following duties: Supervise all library services and operations; establish and maintain appropriate pol:uies and procedures for administering the affairs of the 1ibrary; prepare and administer the library budget; review and monitor personnel decisions; evaluate, select, and implement new library and information technologies; develop and maintain open 1 ines of communication with students, faculty, administration, and the community at large; perform other duties and tasks as assigned by the Vice President for Academic Affairs. Minimum qualifications: ALA-accredited graduate degree in library science and an earned doctorate in a related field preferred. Minimum of 5 years academic library experience; at least 3 of which must be in library administration. Experience in administering technological innovations in library automated services. Active involvement in professional associations. In addition, there must be evidence that the applicant is highly skilled in interpersonal relationships and management techniques, and exhibits effective leadership ability. Evidence of the ability to articulate the role of the library within the university and the community at large must be shown. Annual salary is $\$ 40,000$ range with outstanding fringe benefits package. Nominations or applications, with resume, including names, addresses, and phone numbers of 5 professional references must be received by January 19, 1987. Personnel Office, Bibb Graves Hall, Jacksonville State University, Jacksonville, AL 36265. Jacksonvillle State University is an equal opportunity, affirmative action employer.

MEDIA LIBRARIAN to coordinate Media/A-V services to the University community. Major duties include supervising the library Media Center, facilitating 
equipment distribution, participating in planning library programs, providing instruction in Media Methods and Information Science, coordinating bibliographic instruction, and providing some general reference service. Minimum qualifications include an MLS from an ALA-accredited library school plus a 2nd graduate degree in Media/A-V. Reports to Director of Libraries. Tenure track appointment with faculty status. Salary commensurate with background and experience. Position available fall term 1987. Send resume and the names of 3 references to: Clayton Highum, Director of Libraries, Illinols Wesleyan University, Sheean Library, Bloomington, IL 61702. IWU is an equal opportunity employer.



(Washington Hotline, cont'd)

to authorize $\$ 1$ million for library acquisition of foreign periodicals. There was a spontaneous burst of applause from the observing lobbyists, because it was about the first agreement reached on a programmatic difference. That break in the logjam was followed by a trade on title II issues. The Senate agreed to accept the House II-D technology grants, and the House agreed to give up a $\$ 75,000$ authorization for the evaluation study by the National Commission on Libraries and Information Science of the II-A need criteria for college library grants, although the requirement for the study remained in place.

One important title II issue remained: How much of that $\$ 10.2$ billion cap would title II get as an authorization or ceiling above which funding could not rise, and how would it be divided among title II programs? Dividing up the cap was the last issue decided. The House proposed a package which included $\$ 29$ million for title II. The Senate counter-offer had only $\$ 20$ million. There seemed to be an impasse, and conferees were running out of time since adjournment was scheduled for october 3 . Senate conferees, although including solid library supporters such as Sen. Claiborne Pell (D-RI), were reluctant to provide growth room for non-student aid provisions, and particularly for unfunded programs. House members were just as adamant about the importance of certain non-student aid titles.

Finally, the Senate agreed to an additional $\$ 25$ million for institutionbased aid, to be divided up as the House conferees wished. Reps. Charles Hayes (D-IL) and Major Owens (D-NY) insisted that $\$ 10$ million of that sum be added to the $\$ 20$ million in the Senate offer for title II. Rep. Ford quickly summarized his colleagues' consensus, and Ford and Stafford agreed they had a deal. The conference agreement was later agreed to by the full House and Senate, and signed into law (PL 99-498) by the President.

So title II was reauthorized at $\$ 30$ million, divided $\$ 10$ million for II-A library resources grants targeted to needy colleges, $\$ 5$ million for II-B training and research, $\$ 10$ million for II-C major research library grants, and $\$ 5$ million for II-D technology and cooperation grants. Library program authorizations are above current funding ( $\$ 7$ million) by a higher percentage than almost any other HEA program area.

The next challenge for the academic library community is to work HARD for actual funding, especially for the unfunded II-A and II-D. We must work for funding because libraries need it, but also to show our HEA library champions that they did not work for us in vain. Champions won't remain champions unless constituents thank them and follow it up with hard work on funding. Please be alert to calls for action on this next year. 


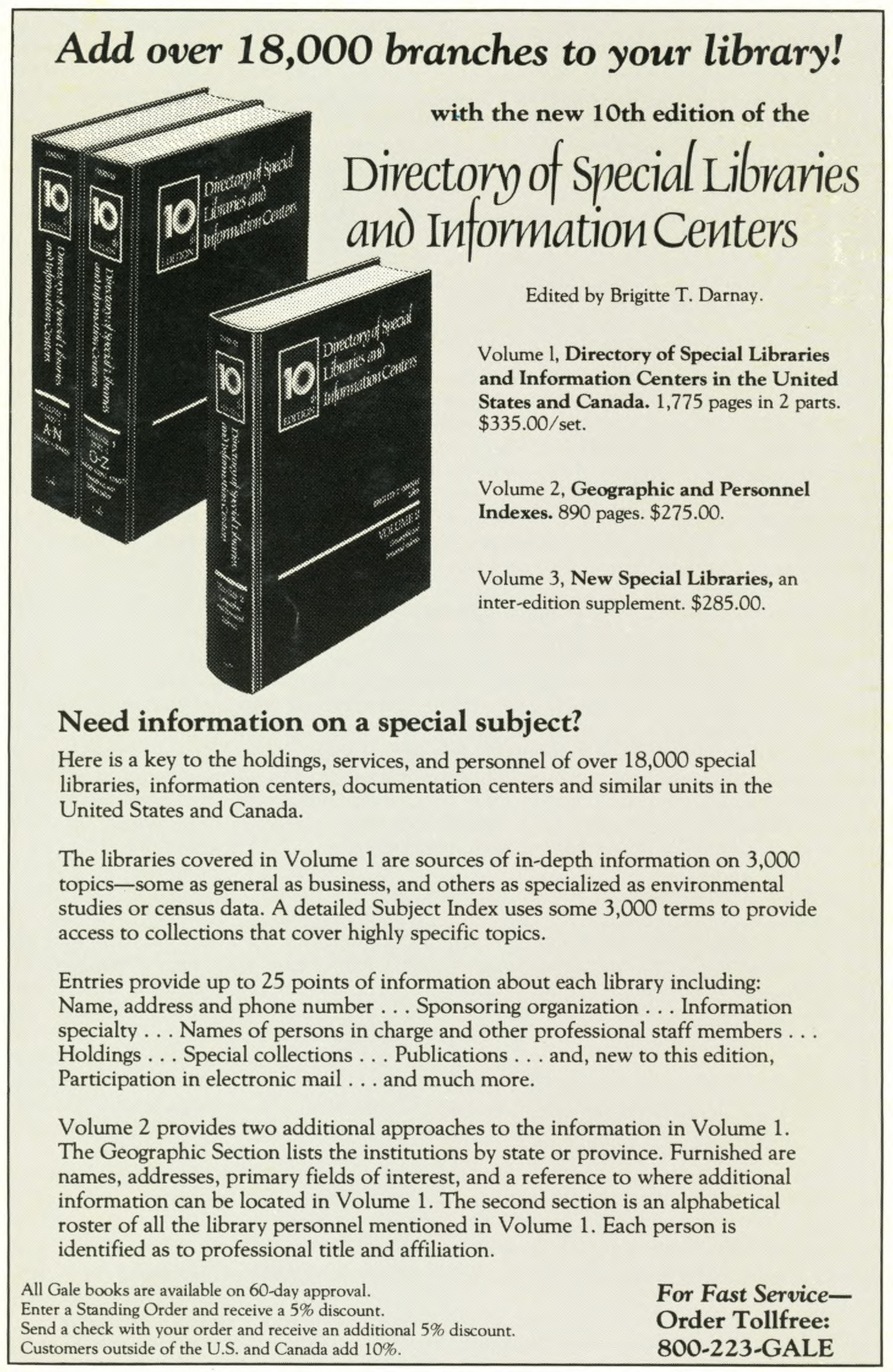

Gale Research Company • Book Tower • Detroit, MI 48226 